\title{
STUDENTS' DESCRIPTIVE WRITING PERFORMANCE: THE ANALYTIC SCORING ASSESSMENT USAGE
}

\author{
Didik Rinan Sumekto ${ }^{1}$, Heny Setyawati² \\ ${ }^{1} \sim$ Widya Dharma University, Klaten, ${ }^{2} \sim$ Semarang State University \\ e-mail: ${ }^{1} \sim$ didikrinan@unwidha.ac.id ${ }^{2} \sim$ henysetyawati@mail.unnes.ac.id
}

\begin{abstract}
This study explores students' performance in descriptive writing. Forty-five English Education sophomore students participated to be the respondents. The data were collected from students' descriptive writing performance using a 5-Likert scale and they were quantitatively analyzed through the descriptive and factor analysis tests. Students' descriptive writing were measured through the components of grammar $(M=3.00 ; S D=.476)$, punctuation $(M=3.93 ; S D=.495)$, coherence $(M=3.60 ; S D=.539)$, cohesion $(M=3.22 ; S D=.517)$, and content $(M=3.51 ; S D=.894)$. Other substantial findings corresponded with the principal component analyses that determined the presence of 5 components with the eigenvalue outreaching 1, positioning $31 \%, 27.3 \%, 19.7 \%, 12.6 \%$, and $9.4 \%$ of the variances accordingly. This referred to the factorial analysis that claimed 2 extracted components with a total of $58.32 \%$ of the variance. The component 1 was $31.00 \%$ and component 2 was $27.32 \%$. The interpretation of these components is coherent with the pilot results on the descriptive writing performance scale, in which the component 1 shows the positive affect items and the component 2 partially indicates the negative affect items.
\end{abstract}

Keywords: Analytic scoring, descriptive writing, factor analysis

\section{PENINGKATAN MENULIS DESKRIPTIF MAHASISWA: PENERAPAN ASESMEN PENSKORAN ANALITIK}

\begin{abstract}
Abstrak: Penelitian ini mengeksplorasi capaian peningkatan mahasiswa dalam menulis esai deskriptif. Empatpuluh lima mahasiswa pendidikan Bahasa Inggris berpartisipasi sebagai responden. Pengumpulan data diambil melalui hasil esai deskriptif mahasiswa dengan menggunakan 5 skala Likert dan analisis data dilakukan secara kuantitatif melalui uji deskriptif dan analisis faktor. Esai deskriptif mahasiswa diraih melalui komponen gramatika (Rerata $=3,00$; Simpangan Baku $=0,476)$, tanda baca (Rerata $=$ 3,93; Simpangan $\mathrm{Baku}=0,495)$, koherensi (Rerata $=3,60$; Simpangan Baku $=0,539)$, kohesi (Rerata $=3,22$; Simpangan Baku $=0,517)$, dan konten (Rerata $=3,51$; Simpangan Baku $=0,894)$. Temuan substansi lainnya terkait dengan analisis komponen utama yang menetapkan 5 komponen dengan raihan 1 nilai eigen yang menempatkan $31 \%, 27,3 \%, 19,7 \%, 12,6 \%$, dan $9,4 \%$ varian. Temuan ini merujuk pada analisis faktor dengan 2 komponen yang diraih sebesar 58,32\% dari keseluruhan varian, di mana komponen 1 sebesar 31,00\% dan komponen 2 sebesar 27,32\%. Tafsiran atas 2 komponen ini koheren dengan hasil awal skala capaian peningkatan esai deskriptif, di mana komponen 1 menunjukkan butir positif dan komponen 2 menunjukkan sebagian butir negatif.
\end{abstract}

Kata Kunci: Penskoran analitik, esai deskriptif, analisis faktor

\section{INTRODUCTION}

In the recent years, the lecturers frequently promote how to become creative to their students in dealing with the writing creativity, although they have the various meanings of creativity and even some students are still difficult to understand what is meant by being creative (Randi \& Jarvin, 2006). So far, writing typically presents a tremendous challenge to higher education students, particularly for sophomore students. Loreto and McDonough (2013) point out that writing can provoke anxiety among students. Writing anxiety refers to a situation-specific individual difference that reflects students' inclination to approach or avoid situations requiring writing, along with the evaluative perceptions. For example, descriptive writing instruction has emphasized the writing 
structure substantively, fulfilled the function of writer's intention, and considered adequate as well (Penner, 2007). It means when writing paragraphs, students conditionally manipulate some aspects of writing, such as syntactic and morphological structures of sentences in order to express their ideas (Schirmer, Bailey, \& Fitzgerald, 1999).

On the other hand, a high-stake testing is still used to measure students' achievements upon their grading levels, mappings, and punishments that categorize students into fast and or slow learners (Meisels, Xue, \& Shamblott, 2008). When students' experience contributed to writing performance, they learned the code system via taking-apart and built up learning (Maraschiello, 2003). Students' essays can be possibly perfect when the feedback is gained from both teacher and peers, who review the writing components, such as spelling, grammar, punctuation, capitalization, etc to produce the effective compositions (Nezakatgoo, 2011), as well as adopt the model of the character-based learning that complies with the honesty, sense of care, communication, and collaboration (Prastika, Setiawati, \& Sumekto, 2018). The model may conditionally alters the learning approach that helps the students develop their skills (Sumekto, 2018). Recently, writing has become more important as principles of communicative language teaching rather than as an object of study. This means that writing is viewed as either a standardized system of communication or as an essential instrument for learning (Weigle, 2002), since the interaction and individual performance by means of classroom learning participation has been contributed (Sumekto, 2014a). On the other hand, lecturers' feedback basically had better cover all aspects of content, organization, grammar, vocabulary, and mechanics) through some commentaries (Telçker \& Akcan, 2010) that lead to students to be more active in writing improvement (Loreto \& McDonough, 2013).

The writing feedback is meant as a process of collecting and documenting students' learning evidence and progress to deal with the informatively instructional, placement, programmatic, and evaluative decisions (Lenski, Ehlers-Zavala, Daniel, \& Sun-Irminger, 2006) through the use of analytic rubric. The analytic rubric may impact the scoring processes substantially even the processes are time-consuming as typically assessing several different skills and individually requiring a lecturer to examine the product several times. Its implementation determines the specific feedback on students' performance with the respect to each individual scoring criteria (Mertler, 2001). Jonsson and Svingby (2007) support the analytic rubric intensively as a means of assessing higher-order thinking processes and solving the problems. The rubric used to indicate the writing samples that evaluate individual features of a text to determine the value of the text as a whole. The rubric is generic and not only specific to the particular writing genres. The overall scores are designed by adding the score assigned for each feature. Scores can be conditionally weighted in variances, so that features like thesis, organization, and development award are more significant in the overall scoring than other features like grammar, mechanics, and usage (O’Neill, Moore, \& Huot, 2009).

In a scoring system, the writing samples are rated on several important aspects of quality to capture students' weaknesses and strengths and work with raters' decision-making processes (Lee, Gentile, \& Kantor, 2008). The rubric is specifically classified to increase judgment consistency when promoting the learning, assessing assignments, authentic tasks, and achievements as well as accommodating valid performance assessment that cannot be achieved by means of the conventional written tests (Jonsson \& Svingby, 2007). The advantages to this analytic scoring provide more information about the test takers' performance. It earns useful diagnostic feedback on writing ability and additional information about students' writing ability that accommodate the placements and decisions (Wiseman, 2008).

The rubric contains a scale of points with specific descriptors which are used to evaluate writing pieces. Martinez (1997) emphasizes the points generally range from zero to four (a 4-point rating scale), whilst four is being the highest possible score. The rubric shall be written in the concise language and includes a scoring point for any level of performance. Martinez recommends that the use of rubric provides a set of criteria that is used to evaluate students' writing. These guidelines are designed to focus on the originality, details, fluency, imagination, and content of the document, rather than judge the work on grammatical usage and spelling, as 
practiced in the past. The rubric is the worthy instrument to use during the writing process, both for instructional and referral purposes, which enables students to be active in the feedback processes. Polston (2013) supports that the results connecting to the product creativity rubric has the positive impact on students' perceptions of receiving feedback from peers as shown through the observations.

Meletiadou (2012) postulates that peer feedback is a rather controlled type of rubric in the form of a checklist that provides marks and feedback. The rubric is designed to apply for the easy and simple both peers and students give comments and basic guidelines for marking the critical and effective writing with a 4-point rating scale. Peer's markings upon some writing samples are highlighted as well. Qu and Yang (2010) reflect that feedback is substantially based on student-centered approach. This motivates students in gaining a better writing, gives multiple directions in the classroom activities, and raises students' cognitive awareness. Meanwhile, Spence (2010) offers the applicably formatted rubric into a 6-point rating scale method of negatively worded descriptors for the low scores (1 to 3 ), and mostly positively worded descriptors for the high scores (4 to 6). The rubric illustrates division between negative and positive wording, in terms of no clear sense of a beginning or ending, the beginning and ending are missing and poorly developed, or both can be too short and long, the writing has an inviting beginning and a satisfying ending. Matsuno (2009) claims the analytic scaling grid shall be supported to be generally more reliable and informative. Each category is divided into a couple of feedback criteria that is weighted proportionally with a 6-point rating scale. Hence, the more categories are included on a rating scale, the more possibly specific judgments are increased. O'Neill, Moore, and Huot (2009) addressed the analytic scoring rubric for general business writing feedback that is also weighted with a 6-point rating scale, so-called by the feedback characteristics. The components consist of evidence and analysis, focus, complexity, coherence, and audience awareness.

Some studies portrayed the empirical feedback practices. Baksh, Sallehhudin, Tayeb, \& Norhaslinda (2016) argued that different students' language medium and academic achievement might have impacted their learning ways and assessment perceptions, as the intended wash-back was still at the beginning level due to many doubts and the influential testing-precedence inevitably became one of them. Accordingly, teaching method integrated assessment supports to the pre-service teachers by offering multiple-levels of their academic's low to high backgrounds that accommodated their learning needs (Jansrisukot, 2016). Mubarok (2017) revealed his findings of writing feedback contribution that involved 32 freshmen in the second semester at an Islamic University in Jepara, Indonesia. The mean of writing before the revision was 6.6 but after the revision, their mean increased 7.9. Empirically, the analytic scoring analyzed and corrected mistakes and weaknesses of writing samples, such as forming words, phrases, sentences, grammar, subject and verb agreement, plural form, developing the main idea and supporting sentences, and anticipating ideas overlapping.

Moreover, Gulley (2012) believed that written feedback was the oversight method for some writing teachers to react their students' writing so far, despite it was still mechanically handled as the control measure and students' developmental writing structurally did revisions to their drafts after receiving some feedback. The feedback's content might role as the substantial factor in determining whether students think that peer feedback was fair enough after they afforded with its processes and concerned about the grades fairness earned from peers that indicated positive and useful feedback (Kaufman \& Schunn, 2011). Sumekto (2014b) pointed out student's expectations on peer feedback. Apart from his study, he reported 66 per cent or 118 out of 179 students put peer feedback on the writing process as a very important component, if a collaboration among students was initiated (Sumekto, Saleh, Retmono, \& Sofwan, 2015). Students were helped by involving themselves in the collaborative writing works $(M=54.09$; $S D=5.642$ ). Sumekto (2017) continued that the pre-service English teachers' collaborative genre-based writing and its collective feedback improved significantly $(p<.01)$ after they attended series of genre-based writing classes. The paired t-test showed the recount paragraph $(M=2.744 ; S D=1.347)$, narrative paragraph $(M$ $=2.767 ; S D=1.771)$, and descriptive paragraph 
$(M=3.488 ; S D=1.594)$ also increased. The correlation coefficients $(P)$ showed $r=.30$ and $p<.05$ after the experimental groups joined in three different lesson plans relating to the genrebased writing.

This present study proposes two research questions in the following: (1) Does the use of rubric enhance the valid judgment through the validity and reliability scoring system? (2) Does the use of rubric promote sophomores' learning and improve lecturer's instruction? Although the use of rubric is to gain a particular interest, the utility may be limited by the scoring rubric quality addressed to rate sophomores' performance and may seem plausible. Hence, this study objective aims to perform students' descriptive writing in relevance with the research design accordingly on the analytic scoring assessment functions.

\section{METHOD}

This study was carried out at undergraduate sophomores of English Education Department, Sarjanawiyata Tamansiswa University in Yogyakarta. There were 45 of 80 sophomore students randomly selected to be the respondents in this study. The study was carried out during the running odd semester of a 20 -week. The researchers firstly observed the lecturer's writing class for two days a week. During his 20 weeks of the writing schedule, a particular lesson plan on descriptive writing was provided 4 times for class A and B. The sophomore students produced two essays in the intermediate level. They had first, second, and final draft for each essay that had been revised by their lecturer. All written feedback on each draft was provided during the class session. The last week of meeting up with all students, the lecturer announced them to submit their final draft. Upon the lecturer's permission, these final drafts were used to reconcile the data collection.

Written assessment on the first draft involved grammar and punctuation components. The lecturer used an error checklist to focus on grammatical accuracy and word choices. The lecturer identified the error location by underlining the errors and writing errors' specific symbol as done in the first draft. Next, he checked marks for the errors that had been produced by the students as the second draft. In the final draft, the lecturer wrote written commentaries in the form of text-specific statements and or questions as well as a brief summary of grammar, punctuation, cohesion, coherence, and content component. These modified commentaries were based on the analytic rubric by Kaven's (2013) development of a valid and reliable general analytic rubric for a college-level course. The analytic scoring rubric involved a five-point scale for each of the five writing components, namely: grammar, punctuation, coherence, cohesion, and content. The rubric was modified through a comprehensive content-validation process to align the descriptors in each component.

The assessment procedures were undertaken as follows: the first draft was set as an in-class assignment and possibly continued as students' home-work. After the students produced the first essay, the lecturer provided the written feedback. The second draft related to the second essay, after the first draft was entirely given a feedback. Sophomores made revisions outside the writing session. The final draft was provided by the lecturer through the oral and written feedback in the classroom. After all, the final essays were rated through the analytic scoring rubric.

The data were collected from the writing test to measure sophomores' descriptive essay performance. 45 sophomores of class A and B were assigned to write a guided descriptive essay as documented in lecturer's teaching syllabus. Prior to handling the descriptive essay, other 27 sophomores of class $\mathrm{C}$ and $\mathrm{D}$ were required to write the descriptive essay for obtaining the Cronbach's alpha coefficients. The results showed that sophomores' grammar was .261, punctuation was .384 , coherence was 321 , cohesion was .469 , and content was .277 . According to Pallant (2007), these results provided an optimal range for the inter-item correlation of 2 to .4. The scale mean ranged in between 16.74 to 17.27 . The scale mean confirmed the measured difference as if it contributed the descriptive essay components.

Data Analysis used sophomores' descriptive essays that were quantitatively examined through the descriptive and factor analyses. All descriptive essays were read twice and coded, whilst notes-taking were directly provided on the transcriptions relating to organizing themes. The rating was based on the total number of errors and inappropriateness produced. The revision types the sophomores produced were on the basis of lecturer's written feedback. 


\section{FINDINGS AND DISCUSSION Findings}

First of all, the data analysis of the grammar component described the descriptive and frequencies statistics results through Table 1 and Figure 1, as follows: 5 or $11.1 \%$ sophomores performed their grammar skill with a poor rank, 35 or $77.8 \%$ sophomores indicated that their grammar skill were in a fair level, and another 5 or $11.1 \%$ showed their grammar skill with a good level. Meanwhile, there was no sophomore achieving both fail and excellent results in the grammar skill to perform their descriptive essay. The finding also recorded that the lowest score of grammar component gained 2.00 and the highest score was 4.00 through the analytic scoring assessment. Meanwhile, the mean was 3.00 and the standard deviation was $.477(n=45)$. The overall achievement of grammar component was on fair category with $77.8 \%$.

Table 1. Sophomores' Grammar Component Achievement

\begin{tabular}{cccccc}
\hline & & $\begin{array}{c}\text { Fre- } \\
\text { quency }\end{array}$ & Percent & $\begin{array}{c}\text { Valid } \\
\text { Percent }\end{array}$ & $\begin{array}{c}\text { Cumulative } \\
\text { Percent }\end{array}$ \\
\hline \multirow{4}{*}{ Valid } & 2.00 & 5 & 11.1 & 11.1 & 11.1 \\
& 3.00 & 35 & 77.8 & 77.8 & 88.9 \\
& 4.00 & 5 & 11.1 & 11.1 & 100.0 \\
& Total & 45 & 100.0 & 100.0 & \\
\hline
\end{tabular}

As summarized in Table 1, the score distribution on grammar component was shown graphically using the histogram (Figure 1).

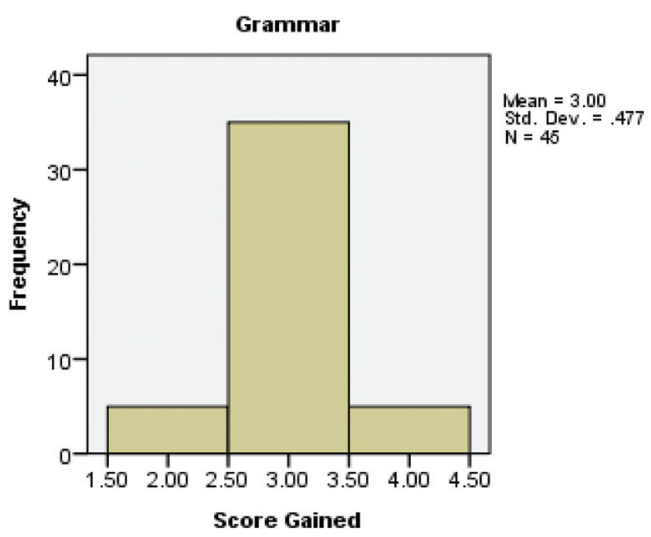

Figure 1. Sophomores' Score Gained in Grammar Component

Second, the data analysis of the punctuation component verified the descriptive and frequencies statistics results through Table 2 and Figure 2, as follows: 3 or 7\% sophomores performed their punctuation skill with a fair level, 34 or $75.6 \%$ indicated their punctuation was in a good level, and 4 or $8.9 \%$ sophomores indicated their punctuation skill with an excellent level. Meanwhile, there was no sophomore earning either fail or poor level in the punctuation skill. The finding also documented that the lowest score of the punctuation component earned 3.00 and the highest score was 5.00 through the analytic scoring assessment. Meanwhile, the mean was 3.93 and the standard deviation was $.495(n=$ 45). The overall achievement of the punctuation component was on good category with $75.6 \%$.

Table 2. Sophomores' Punctuation Component Achievement

\begin{tabular}{cccccc}
\hline & & $\begin{array}{c}\text { Fre- } \\
\text { quency }\end{array}$ & Percent & $\begin{array}{c}\text { Valid } \\
\text { Percent }\end{array}$ & $\begin{array}{c}\text { Cumulative } \\
\text { Percent }\end{array}$ \\
\hline \multirow{4}{*}{ Valid } & 3.00 & 7 & 15.6 & 15.6 & 15.6 \\
& 4.00 & 34 & 75.6 & 75.6 & 91.1 \\
& 5.00 & 4 & 8.9 & 8.9 & 100.0 \\
& Total & 45 & 100.0 & 100.0 & \\
\hline
\end{tabular}

As documented in Table 2, the score distribution on the punctuation component was portrayed graphically using the histogram (Figure 2).

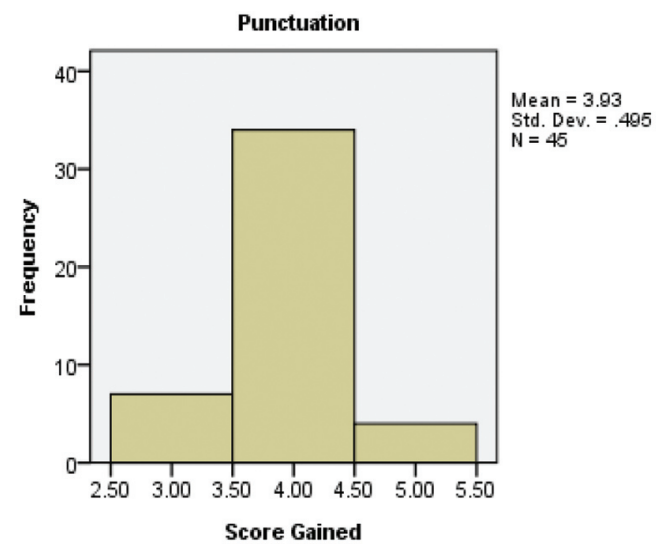

Figure 2. Sophomores' Score Gained in Punctuation Component

Third, the data analysis of the coherence component verified the descriptive and frequencies statistics results through Table 3 and Figure 3, as follows: 19 or $42.2 \%$ sophomores performed their coherence skills were in a fair level, 25 or $55.6 \%$ sophomores indicated their coherence skills were in good level, and only 1 or $2.2 \%$ sophomore's coherence skills indicated an excellent level. Meanwhile, there was no 
sophomore performing either fail or poor level in coherence skills. The finding also noted that the lowest score of coherence component earned 3.00 and the highest score was 5.00 through the analytic scoring assessment. Meanwhile, whilst the mean was 3.60 and the standard deviation was $.539(n=45)$. The overall achievement of the coherence component was on good category with $55.6 \%$.

Table 3. Sophomores' Coherence Component Achievement

\begin{tabular}{cccccc}
\hline & & $\begin{array}{c}\text { Fre- } \\
\text { quency }\end{array}$ & Percent & $\begin{array}{c}\text { Valid } \\
\text { Percent }\end{array}$ & $\begin{array}{c}\text { Cumulative } \\
\text { Percent }\end{array}$ \\
\hline \multirow{4}{*}{ Valid } & 3.00 & 19 & 42.2 & 42.2 & 42.2 \\
& 4.00 & 25 & 55.6 & 55.6 & 97.8 \\
& 5.00 & 1 & 2.2 & 2.2 & 100.0 \\
& Total & 45 & 100.0 & 100.0 & \\
\hline
\end{tabular}

As documented in Table 3, the score distribution on the coherence component was gained graphically using the histogram (Figure $3)$.

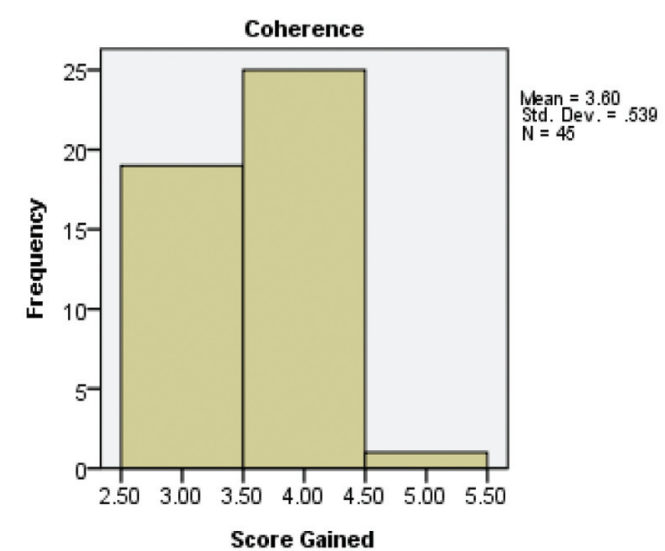

Figure 3. Sophomores' Score Gained in Coherence Component

Fourth, data analysis of the cohesion component determined the descriptive and frequencies statistics results through Table 4 and Figure 4, as follows: 2 or $4.4 \%$ sophomores performed their cohesion skills with a poor level, 31 or $68.9 \%$ sophomores indicated their cohesion skills were in a fair level, and 12 or $26.7 \%$ sophomores showed their cohesion skills with a good level. Meanwhile, there was no sophomore indicating their performance either fail or excellent level in the cohesion skills. The finding also noted that the lowest score of cohesion component gained 2.00 and the highest score was 4.00 through the analytic scoring assessment. Meanwhile, the mean was 3.22 and the standard deviation was $.517(n=45)$. The overall achievement of the cohesion component showed fair category with $68.9 \%$.

Table 4. Sophomores' Cohesion Component Achievement

\begin{tabular}{cccccc}
\hline & & $\begin{array}{c}\text { Fre- } \\
\text { quency }\end{array}$ & Percent & $\begin{array}{c}\text { Valid } \\
\text { Percent }\end{array}$ & $\begin{array}{c}\text { Cumulative } \\
\text { Percent }\end{array}$ \\
\hline \multirow{4}{*}{ Valid } & 2.00 & 2 & 4.4 & 4.4 & 4.4 \\
& 3.00 & 31 & 68.9 & 68.9 & 73.3 \\
& 4.00 & 12 & 26.7 & 26.7 & 100.0 \\
& Total & 45 & 100.0 & 100.0 & \\
\hline
\end{tabular}

As summarized in Table 4, the score distribution on the cohesion component was displayed graphically using the histogram (Figure 4).

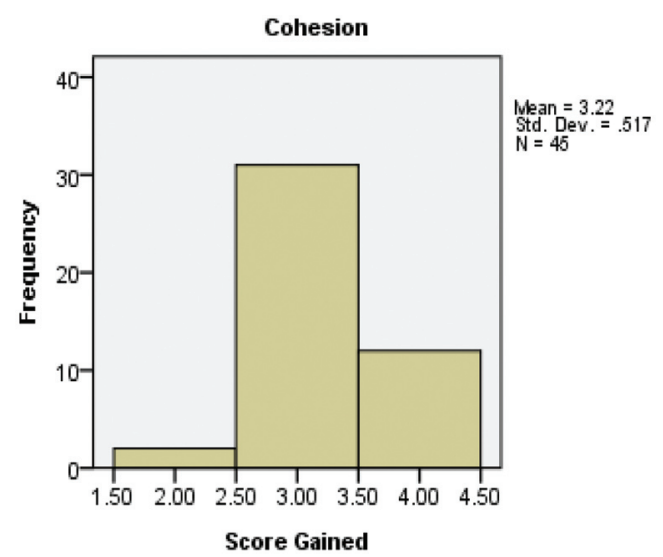

Figure 4. Sophomores' Score Gained in Cohesion Component

Fifth, the data analysis of the content component determined the descriptive and frequencies statistics results through Table 5 and Figure 5, as follows: 5 or $11.1 \%$ sophomores performed their content skills were in a poor level, 19 or $42.2 \%$ sophomores verified their content skills were in a fair level, 14 or $31.1 \%$ sophomores proved their content skills were in good level, and 7 or $15.6 \%$ sophomores showed their content skills were excellent. Meanwhile, there was no sophomore indicating that their contents skills were poor. The finding also recorded that the lowest score of the content component was 2.00 and the highest score was 5.00 through the analytic scoring assessment. However, the mean was 3.51 and the standard deviation was .895 $(n=45)$. The overall 
achievement of the content component was on fair category with $42.2 \%$.

Table 5. Sophomores' Content Component Achievement

\begin{tabular}{cccccc}
\hline & & $\begin{array}{c}\text { Fre- } \\
\text { quency }\end{array}$ & Percent & $\begin{array}{c}\text { Valid } \\
\text { Percent }\end{array}$ & $\begin{array}{c}\text { Cumulative } \\
\text { Percent }\end{array}$ \\
\hline \multirow{4}{*}{ Valid } & 2.00 & 5 & 11.1 & 11.1 & 11.1 \\
& 3.00 & 19 & 42.2 & 42.2 & 53.3 \\
& 4.00 & 14 & 31.1 & 31.1 & 84.4 \\
& 5.00 & 7 & 15.6 & 15.6 & 100.00 \\
\hline & Total & 45 & 100.0 & 100.0 &
\end{tabular}

As confirmed by Table 5, the score distribution on the content component was documented graphically using the histogram (Figure 5).

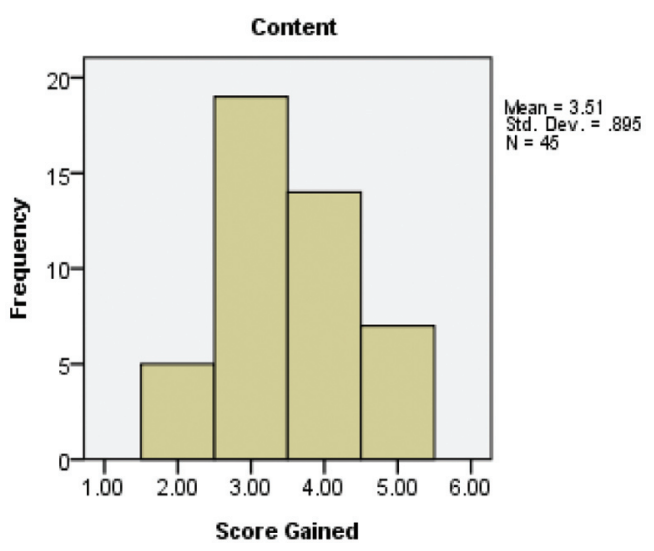

Figure 5. Sophomores' Score Gained in Content Component

The descriptive essay skills addressed to the contributing components of grammar, punctuation, coherence, cohesion, and content. 45 undergraduate sophomores of English Education Department participated in writing class. The results of sophomores' descriptive essay as shown in Table 6 were resulted in the following components: grammar $(M=3.00$; $S D=.476)$, punctuation $(M=3.93 ; S D=.495)$, coherence $(M=3.60 ; S D=.539)$, cohesion $(M=$ 3.22; $S D=.517)$, and content $(M=3.51 ; S D=$ $.894)$. The analytic scoring assessment was set in a 5-point-Likert scale to figure out sophomores' descriptive essay performance. Further, the statistics for grammar's skewness (.000) and kurtosis (1.827), punctuation's skewness (-.162) and kurtosis (1.320), coherence's skewness (.036) and kurtosis (-1.079), cohesion's skewness (.284) and kurtosis (.031), and content's skewness (.164) and kurtosis (-.676) were inconsiderable for 45 students' descriptive essays. From the results of the skewness and kurtosis in the descriptive essay components, the data were normally distributed. The lowest mean gained in the essay component was grammar and the highest mean was punctuation.

Next analysis discussed on the chisquare test for goodness of fit as shown in Table 7. This analysis identified five components on the descriptive essay, in which the results corresponded with sophomores' descriptive essay performance in the different categories. The overall difference among these chi-square's descriptive essay components were statistically significant, where $\mathrm{c}^{2}=40.000(2, n=45)$, $p<.000$ for the grammar, $\mathrm{c}^{2}=36.400(2, n=45)$, $p<.000$ for the punctuation, $\mathrm{c}^{2}=20.800(2, n=$ $45), p<.000$ for the coherence, $\mathrm{c}^{2}=28.933(2, n=$ $45), p<.000$ for the cohesion, and $\mathrm{c}^{2}=11.089$ (3, $n=45), p<.011$ for the content. Therefore, a chisquare test for goodness of fit showed that there was no significant difference in the majority proportion of sophomores' descriptive essay shown in the sample size $(n=45)$.

a. 0 cells $(.0 \%)$ have expected frequencies less than 5 . The minimum expected cell frequency is 15.0 .

b. 0 cells $(.0 \%)$ have expected frequencies less than 5 . The minimum expected cell frequency is 11.3 .

Table 6. Overall Sophomores' Descriptive Essay Achievements

\begin{tabular}{lccccccccc}
\hline \multirow{2}{*}{$\begin{array}{l}\text { Descriptive Essay } \\
\text { Components }\end{array}$} & $\mathrm{N}$ & Min. & Max. & Mean & Std. Dev. & \multicolumn{2}{c}{ Skewness } & \multicolumn{2}{c}{ Kurtosis } \\
\cline { 2 - 9 } & Statistic & Statistic & Statistic & Statistic & Statistic & Statistic & $\begin{array}{c}\text { Std. } \\
\text { Error }\end{array}$ & Statistic & $\begin{array}{c}\text { Std. } \\
\text { Error }\end{array}$ \\
\hline Grammar & 45 & 2.00 & 4.00 & 3.0000 & .47673 & .000 & .354 & 1.827 & .695 \\
Punctuation & 45 & 3.00 & 5.00 & 3.9333 & .49543 & -.162 & .354 & 1.320 & .695 \\
Coherence & 45 & 3.00 & 5.00 & 3.6000 & .53936 & .036 & .354 & -1.079 & .695 \\
Cohesion & 45 & 2.00 & 4.00 & 3.2222 & .51737 & .284 & .354 & .031 & .695 \\
Content & 45 & 2.00 & 5.00 & 3.5111 & .89499 & .164 & .354 & -.676 & .695 \\
Valid N (listwise) & 45 & & & & & & & & \\
\hline
\end{tabular}


Table 7 Chi-Square Test for Goodness of Fit Results

\begin{tabular}{lrrrrr}
\hline & Grammar & Punctuation & Coherence & Cohesion & Content \\
\hline Chi-Square & $40.000^{\mathrm{a}}$ & $36.400^{\mathrm{a}}$ & $20.800^{\mathrm{a}}$ & $28.933^{\mathrm{a}}$ & $11.089^{\mathrm{b}}$ \\
$\mathrm{df}$ & 2 & 2 & 2 & 2 & 3 \\
Asymp. Sig. & .000 & .000 & .000 & .000 & .011 \\
\hline
\end{tabular}

Table. 8. Descriptive Statistics of Sophomores' Descriptive Essay Performance

\begin{tabular}{lccccccc}
\hline \multirow{2}{*}{ Component } & \multicolumn{2}{c}{ Initial Eigenvalues } & \multicolumn{2}{c}{ Extraction Sums of Squared Loadings } & \multicolumn{2}{c}{$\begin{array}{c}\text { Rotation Sums of Squared } \\
\text { Loadings }^{\mathrm{a}}\end{array}$} \\
\cline { 2 - 8 } & Total & \% of Variance & Cumulative \% & Total & \% of Variance & Cumulative \% & Total \\
\hline Grammar & 1.550 & 31.007 & 31.007 & 1.550 & 31.007 & 31.007 & 1.481 \\
Punctuation & 1.366 & 27.322 & 58.328 & 1.366 & 27.322 & 58.328 & 1.433 \\
Coherence & .984 & 19.675 & 78.004 & N/A & N/A & N/A & N/A \\
Cohesion & .632 & 12.639 & 90.642 & N/A & N/A & N/A & N/A \\
Content & .468 & 9.358 & 100.000 & N/A & N/A & N/A & N/A \\
\hline
\end{tabular}

Extraction Method: Principal Component Analysis.

a. When components are correlated, sums of squared loadings cannot be added to obtain a total variance.

Table 9. Pattern and Structure Matrix for PCA with the Oblimin Rotation of Two-Factor of Descriptive Essay Scales

\begin{tabular}{lccccc}
\hline \multirow{2}{*}{ Descriptive Essay Components } & \multicolumn{2}{c}{ Pattern coefficients } & \multicolumn{2}{c}{ Structure coefficients } & \multirow{2}{*}{ Communalities } \\
\cline { 2 - 5 } & Component 1 & Component 2 & Component 1 & Component 2 & \\
\hline 5. Content & $\mathbf{. 7 5 3}$ & N/A & $\mathbf{. 4 7 4}$ & $\mathbf{. 6 1 3}$ & .606 \\
1. Grammar & $\mathbf{. 6 7 7}$ & -.408 & $\mathbf{7 8 5}$ & N/A & .624 \\
3. Coherence & $\mathbf{. 5 3 8}$ & .684 & N/A & $\mathbf{. 8 7 0}$ & .757 \\
2. Punctuation & $\mathbf{. 4 7 5}$ & -624 & $\mathbf{. 7 5 8}$ & N/A & .615 \\
4. Cohesion & N/A & $\mathbf{. 5 5 1}$ & N/A & $\mathbf{. 5 0 0}$ & .314 \\
\hline
\end{tabular}

Note: major loadings for each item were in boldface

Further, five components of descriptive essay also referred to the principal components analysis (PCA) results. Prior to proving these components, the suitability of the factor analysis data was assessed. The inspection of the correlation matrix showed the presence of available coefficients of .107 and above. Then, the Kaiser Meyer-Olkin (KMO) value was .612 , passing the recommended value of .6 and Bartlett's test of Sphericity was $p=.000$ (Pallant, 2011). This addressed the statistical significance and strengthened the factorability of the correlation matrix. The PCA results derived the presence of five components with the eigenvalue outreaching 1, establishing 31\%, 27.3\%, 19.7\%, $12.6 \%$, and $9.4 \%$ of the variances accordingly, as shown in Table 8 . The scrutiny of the scree plot revealed a definite part after fulfilling five components. The scree plot was determined to withhold two axes for the further study (Figure 6) and supported by the parallel analysis results. This scree plot showed two axes with the eigenvalue outreaching towards the supporting criterion values for a randomly carried out of the available size of matrix data ( 5 components $\mathrm{x} 45$ sophomores).

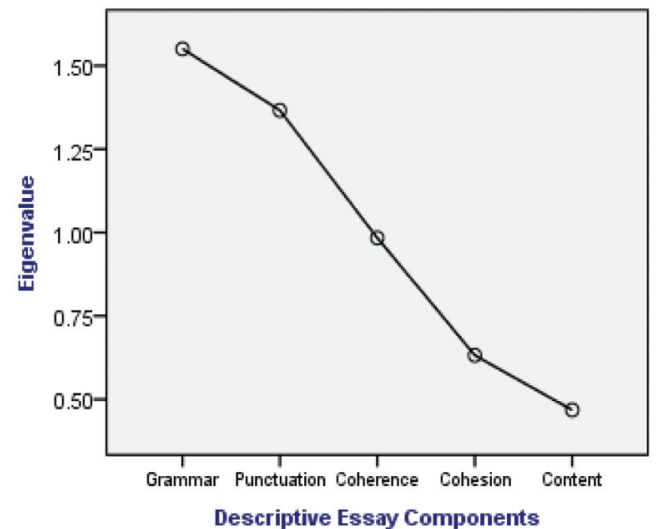

Figure 6. Scree Plot of Sophomores' Descriptive Essay Performance

Moreover, another part of the factorial analysis referred to two extracted components with a total of $58.32 \%$ of the variance. The component 1 was $31.00 \%$, whilst the component 2 was $27.32 \%$. To gain the interpretation of these components, the oblimin rotation was 
confirmed as shown in Table 9. The rotated solution performed the presence of simple structure with both components that resulted a number of squared loadings and five writing components that loaded substantially on the component 1 only. The interpretation of these components was coherent with the pilot results on the descriptive essay performance scale, in which the component 1 showed the positive affect items and the component 2, on the other hand, partially indicated the negative affect items. However, there was a negative correlation between the two factors $(r=-.03)$. This analysis supported the use of either positive or negative affect items as the separated scales.

\section{Discussion}

This study attempts to assess whether the analytic scoring system of the descriptive essay may be applied for an effective instruction method towards sophomores' English education department. As part of the descriptive essay, a comprehensive understanding of this essay is empirically based on sophomores' analytic scoring components, such as grammar, punctuation, coherence, cohesion, and content. Conveyed in sophomores' descriptive essay, a well-formatted writing product commonly begins with the title displayed at the beginning of the writing part. By following the criteria, the title shall be centered and commonly the first letter shall be written or printed in capital letter. When starting to write a new paragraph, the first sentence shall be intended. A writer at least writes three till five sentences before moving to another second paragraph usually with the double-spaces. In accordance with the factual facts, sophomores' descriptive essay still have some requirements to fix. They neglect to write down a simple and concise title, as well as keep writing the paragraphs without intended format. These facts can describe some students' academic background, in which they do not have an appropriate experience with writing aspects before. But, some of them have produced with the correct requirements.

Next component emphasized on grammar, which demonstrates an understanding of the relationship between punctuation and sentence structure (Martinez, 1997). It shall be effective complex construction, indicated few errors of agreement, tense, number, word order or function, articles, pronouns, prepositions (Pappamihiel, Nishimata, \& Mihai (2008; Kargozari, Ghaemi, \& Heravi, 2012). Referring to the grammar competence analyzed from sophomores' average score, the result ranks on the below level. The mean score is 3.00 or on a fair level. The mistakes can vary in the use of most detailed aspects as highlighted by Pappamihiel, Nishimata, \& Mihai, 2008; Kargozari, Ghaemi, \& Heravi, 2012). Meanwhile, the sentence structure mistakes found in sophomores' descriptive essay correlate with the simple, compound, and complex sentence. Some mistakes also contribute in the sentence pattern arrangement, subject and predicate agreement, and either single or paired conjunction which lead to some sentence problems and complexities to understand.

Second component of the descriptive essay relates to sophomores' punctuation skills. Pappamihiel, Nishimata, and Mihai (2008; Kargozari, Ghaemi, \& Heravi, 2012) point out that the conventions mastery eliminate few errors of spelling written in sentences and/ or paragraphs. Sophomores may write with the right capitalization, and began and understand about paragraphing. Regarding the punctuation skill that have been performed by the sophomores, the score ranks on the first level with the mean of 3.93. In the case of sophomores' punctuation skills, there are some mistakes on misspelling words produced in their paragraphs. In an opportunity given to completing the essay, only a few sophomores use technology devices to help them revise the punctuation errors, such as spelling, space, and capitalization.

The third component compromises with the coherence and cohesion. When the researchers conduct the classroom observations, these both components are applied for the feedback purposes separately. The researchers hereby consider that the components shall be used together, as this refers to Meletiadou's recommendation (2012), in which either coherence or cohesion unifies the paragraphs and the sophomores gain the coherence component by using simple linking devices to connect one sentence into another one in a paragraph. According to Martinez (1997) both coherence and cohesion shall present information in a well-organized thought, provide fluent and comprehensive expression, ideas clearly, use the logical sequencing. Meanwhile, Pappamihiel, Nishimata, and Mihai (2008) 
underline the sequence of meanings so that words may stick together and serve the overall meaning of descriptive essay. In accordance with the coherence and cohesion skill, the result ranks on the second level of coherence with the mean score of 3.60, whilst the cohesion earns the fourth level with the mean score of 3.22.

Some common mistakes are found among sophomores' introductory statement, in which the paragraphs do not sharpen the thesis statement of their descriptive essays, besides being compulsory necessary to comprehend a clear topic sentence and unnecessary dealing with more than one idea that does not correspond with the topic sentence. In further, the coherence and cohesion are inappropriately used in sentences to reflect the supporting ideas which address facts and details. The supporting ideas do not harmonize the controlling ideas. In fact, some ideas unnecessary jump out of one sentence to another one, sophomores also need to emphasize the function of the transitional signals that is solely used to connect the sentences. That is why mostly their descriptive essays are not smoothly cohesive and coherent.

The fourth component is linked to sophomores' descriptive essay content. Martinez (1997) includes the appropriate details to support ideas or conclusions in an essay that provide the main ideas clearly and be well-supported to the topic, so that the text is easy to read (Meletiadou, 2012). According to Pappamihiel, Nishimata, and Mihai (2008; Kargozari, Ghaemi, and Heravi, 2012) the content shall be knowledgeable, substantive, thoroughly development of materials or thesis, and relevant to an assigned topic. Relating to sophomores' content skill, the achievement ranks on the third level with the mean score is 3.51. For the better achievements, the sophomores are advised to be aware of their sentences before continuing the next sentences through their comprehensive checks and revisions upon some potential mistakes or mismatches produced upon their descriptive essays.

Another discussion corresponds with the appropriately analytic scoring rubric that needs to be well-prepared and to accommodate all sophomores in using it without leaving for possibly small insufficiency. Before using the rubric, the lecturer has a responsibility to share the substantial points how to work with the rubric items. Commonly, the effective format and purpose of its practice is determined as the appropriate rubric usage. Cyr, Smith, Broyles, \& Holt (2014) verified that a rubric outlines a set of criteria and the standards link to specific learning objectives and may assign a numeric value to coincide with each criteria category, such as grammar, punctuation, coherence, cohesion, and content (Kaven, 2013), as well as separated and weighted the textual components with the a 5-point-Likert scale. Each component, according to Spence (2010) has its own scoring scale with the descriptive statements and sometimes extends to several descriptors, in which the current level of achievement, strengths, and weaknesses can be diagnosed (Amy and Victor, 2008). Thus, the use of the analytic scoring rubric allows for a standardized performance assessment to enhance consistency when subjective assignments and written feedback to sophomores' descriptive essays are possible (Polston, 2013).

However, the analytic scoring system is generally undertaken longer to score a writing sample using an analytic rubric since the lecturer needs to decide the multiple decisions for each writing sample and to read the sample more than one time. The use of an analytic scoring rubric may take attention from overall essay effects. Since the multiple score scales are frequently summated, hence some collected information from those scales will be potentially absurd. Another limitation relates to the distortion information when the lecturer rates the multiple scales he determines the single composite score. The lecturer also extends more time to rate holistically rather than analytically, so that the partial problems of validity and reliability may still occur in the scoring procedure.

\section{CONCLUSION}

The use of analytic scoring rubric enhances the reliability and validity results. Prior to assessing this present study, Cronbach's alpha coefficient has empirically indicated the results in terms of relevant components that concern with the descriptive writing assessment, namely: grammar, punctuation, coherence, cohesion, and content. A 5-point-Likert scale is used to validate Cronbach's alpha and to provide an indication of the average correlation among those five descriptive writing components that deal with the scale. However, the use of the analytic scoring assessment system promotes the writing 
class instruction as part of teaching methodology accomplishing both the sophomores and the lecturer. The findings drive the lecturer continually facilitates the rubric to accommodate sophomores' descriptive essays, recognize the substantial qualities, and integrate the qualities into their own essays insights. Further, the lecturer possibly modifies the analytic rubric that moderately recommends the necessary qualities of descriptive essays or encompasses a wider component of rubrics qualities depending on the essay complexity, such as intermediate, pre-advanced, and advanced writing, as well students' writing competence and maturation. This conclusion entrusts that the analytic scoring rubric implicates the influential scoring system in day-to-day practices.

\section{REFERENCES}

Amy, D., \& Victor, S. (2008). Learning to write and writing to learn in science: Refutational texts and analytical rubrics. Science Scope, 32(3), 14-18.

Baksh, A., Sallehhudin, M. A. A., Tayeb, Y. A., \& Norhaslinda, H. (2016). Washback effect of school-based English language assessment: A case-study on students' perceptions. Pertanika Journal of Social Sciences \& Humanities, 24(3), 10871104.

Cyr, P. R., Smith, K. A., Broyles, I. L., \& Holt, C. T. (2014). Developing, evaluating and validating a scoring rubric for written case reports. International Journal of Medical Education, 5, 18-23.

Gulley, B. (2012). Feedback on developmental writing students' first drafts. Journal of Developmental Education, 36(1), 16-36.

Jansrisukot, J. (2016). A study on the integration of learning outcomes, learning activities and assessments in teacher education. Pertanika Journal of Social Sciences \& Humanities, 24(S), 169-182.

Jonsson, A., \& Svingby, G. (2007). The use of scoring rubrics: Reliability, validity and educational consequences. Educational
Research Review, 2, 130-144. doi: 10.1016/j.edurev.2007.05.002

Kargozari, H. R., Ghaemi, H., \& Heravi, M. A. (2012). Cohesive devices in argumentative, descriptive, and expository writing produced by Iranian EFL university students. Modern Journal of Language Teaching Methods, 2(3), 25-47.

Kaufman, J. H., \& Schunn, C. D. (2011). Students' perceptions about peer assessment for writing: Their origin and impact on revision work. Instructional Science, 39, 387-406. doi: 10.1007/s11251-0109133-6

Kaven, J. (2013). The development of a valid and reliable general analytic rubric for a college-level public-speaking course. (Dissertation). Available from Education Resources Information Center. (ERIC No. 553452)

Lee, Y-. W., Gentile, C., \& Kantor, R. (2008). Analytic scoring of TOEFL CBT essays: Scores from humans and e-rater. New Jersey: ETS.

Lenski, S. D., Ehlers-Zavala, F., Daniel, M. S., \& Sun-Irminger, X. (2006). Assessing English-language learners in mainstream classrooms. The Reading Teacher, 60(1), 24-34. doi: 10.1598/RT.60.1.3

Loreto, S. D., \& McDonough, K. (2013). The relationship between instructor feedback and ESL student anxiety. TESL Canada Journal/ Revue TESL Du Canada, 31(1), 20-41.

Maraschiello, R. F. (2003). Toward establishing the validity and reliability of $a$ developmental writing assessment scale (Dissertation). Available from ProQuest Dissertations and Theses database. (UMI No. 3129089)

Martinez, K. (1997). The effect of a rubric on evaluating and improving student writing. Published Thesis, Caldwell College, New Jersey. 
Matsuno, S. (2009). Self-, peer-, and teacherassessments in Japanese university EFL writing classrooms. Language Testing, 26(1), 75-100.

Meletiadou, E. (2012). The impact of training adolescent EFL learners on their perceptions of peer assessment of writing. Research Papers in Language Teaching and learning, 3(1), 240-251.

Meisels, S. J., Xue, Y., \& Shamblott, M. (2008). Assessing language, literacy, and Mathematics skills with work sampling for head start. Early Education and Development, 19(6), 963-981. doi: 10.1080/10409280801971890

Mertler, C. A. (2001). Designing Scoring Rubrics for Your Classroom. Practical Assessment, Research \& Evaluation, 7(25). Retrieved 3 March 2018, from http://PAREonline. net/getvn.asp? $=7 \& n=25$

Mubarok, H. (2017). Students'Perception toward the Implementation of Peer Assessment in Writing: Before and After Revision. Celt: A Journal of Culture, English Language, Teaching \& Literature, 17(1), 13-26. Doi: 10.24167/celt.v17i1

Nezakatgoo, B. (2011). The effects of portfolio assessment on writing of EFL students. English Language Teaching, 4(2), 231241. doi: 10.5539/elt.v4n2p231

O'Neill., Moore, C., \& Huot, B. (2009). A guide to college writing assessment. Utah: Utah State University Press.

Pallant, J. (2011). SPSS survival manual: A step by step guide to data analysis using SPSS (fourth ed.). New South Wales: Allen \& Unwin.

Pappamihiel, N. E., Nishimata, T., \& Mihai, F. (2008). Timed writing and adult Englishlanguage learners: An investigation of first language use in invention strategies. Journal of Adolescent \& Adult Literacy, 51(5), 386-394.
Penner, I. S. (2007). Comparison of effects of cognitive level and quality writing assessment (CLAQWA) rubric on freshman college student writing. College Student Journal, 447-461.

Polston, K. P. (2013). Self- and peer-assessment of product creativity in a collaborative environment: A research study with undergraduate textile and apparel designers. (Dissertation). Available from ProQuest Dissertations and Theses database. (UMI No. 3690347)

Prastika, W., Setiawati, E. E. D., \& Sumekto, D. R. (2018). Analyzing the eleventhyear-students descriptive writing skills documented in the academic year of 20172018.

Qu, W., \& Yang, S. (2010). A peer and selfassessment project implemented in practical group work. Journal of Language Teaching and Research, 1(6), 776-781.

Randi, J., \& Jarvin, L. (2006). An "A" for creativity: Assessing creativity in the classroom. Thinking Classroom, 7(4), 2632.

Schirmer, B. R., Bailey, J., \& Fitzgerald, S. M. (1999). Using a writing assessment rubric for writing development of children who are deaf. Exceptional Children, 65(3), 383-397.

Spence, L. K. (2010). Discerning writing assessment: Insights into an analytical rubric. Language Arts, 87(5), 337-352.

Sumekto, D. R. (2018). Investigating the influence of think-pair-share approach toward students' reading achievement. Lingua Cultura, 12(2), 195-202. doi: 10.21512/lc.v12i2.4011

Sumekto, D. R. (2017). The effectiveness of preservice English teachers' collaborative genre-based writing feedback. Lingua Cultura, 11(1), 31-38. doi: 10.21512/ lc.v11i1.1595 
Sumekto, D. R., Saleh, M., Retmono., \& Sofwan, A. (2015). Pre-service English teacher's perception on collaborative genre-based writing. The Journal of Educational Development, 3(2), 125-132.

Sumekto, D. R. (2014a). Students' oral skill improvement as revealed in learning-based performance. English Review: Journal of English Education, 3(1), 91-102.

Sumekto, D. R. (2014b, 7-9 October). Higher education students' perception about peer assessment practice. Paper presented at The $61^{\text {st }}$ TEFLIN International Conference 2014, "English Language Curriculum Development: Implications for Innovations in Language Policy and Planning, Pedagogical Practices, and Teacher Professional Development", Indonesia. Retrieved from https://eprints. uns.ac.id/26488
Telçker, H., \& Akcan, S. (2010). The effect of oral and written teacher feedback on students' revisions in a process-oriented EFL writing class. TESL Reporter, 43(1), 31-49.

Weigle, S. C. (2002). Assessing writing. Cambridge: Cambridge University Press.

Wiseman, C. S. (2008). Investigating selected facets in measuring second language writing ability using holistic and analytic scoring methods. (Dissertation). Available from ProQuest Dissertations and Theses database. (UMI No. 3327031) 